\title{
Study on Fire Detection at Cultural Assets Buildings with Botanical Roofs
}

\author{
HIROYUKI TAMURA, DAISUKE KOZEKI and KUNIHIRO YAMASHITA \\ National Research Institute of Fire and Disaster \\ 3-14-1, Nakahara, Mitaka, Tokyo 181, Japan
}

MASATO AIZAWA

Hochiki Corporation

246, Tsuruma, Machida, Tokyo 194, Japan

\begin{abstract}
Burning characteristics of botanical roofs, which are often used for cultural assets buildings in Japan, have been investigated through a series of experiments. Based on the experiments, suitable fire detecting system for such kind of fires are discussed and proposed.

The rate-of-rise heat detectors are installed in the attic, on the ceiling and under the eaves, for cultural assets buildings.

However, in $30 \%$ of fires at cultural assets buildings, fires break out from their roofs and those detectors beneath the roofs are not proved to be suitable for the early detection of such kinds of fires.

For the purpose of earlier detection of the roof-fires, a series of fire experiments, in which the roofs are ignited from outward, are conducted and the rate of the fire spread are observed. In the experiments, sensors of various kinds are installed and the response of them are also evaluated.

Those experiments reveal that fires on the roof surface can be detected in early smoldering stage by smoke detectors with wind, and temperature rise is only detectable at a point just opposite to the fire point at that time.

Flame sensor is proved to be effective to detect roof-fires in very early stage. KEYWORDS : fire detection, cultural assets buildings, wooden house, roof material
\end{abstract}

\section{INTRODUCTION}

Most of Japanese buildings which are registered as cultural assets are wooden, and $40 \%$ of them have roofs thatched with botanical materials. About half of 
cultural assets buildings on fires had botanical roofs and place of an outbreak of fire is roof in $30 \%$ of cultural assets buildings fires.

Nowadays, for the cultural assets buildings with botanical roofs, rate-of-rise heat detectors are installed in the attic, on the ceiling and under the eaves. These installation methods are suitable for fires inside the building but they are not suitable for roof-surface fires. In order to protect cultural assets buildings from fires, the method to detect roof-surface fires at an early stage must be investigated.

We investigated the combustion characteristic of botanical roofs. And considering construction and cost for the automatic alarm system, we studied the technology to detect roof-surface fires more quickly with some detectors which are easy to get.

\section{STRUCTURES OF THE BOTANICAL ROOFS}

\section{THATCHED ROOF}

Thatched roof consists of dry cogongrasses with 3 to $8 \mathrm{~mm}$ in diameter and 1.5 to $2 \mathrm{~m}$ long all over the roof. The thickness of the roof is between 40 and $80 \mathrm{~cm}$.

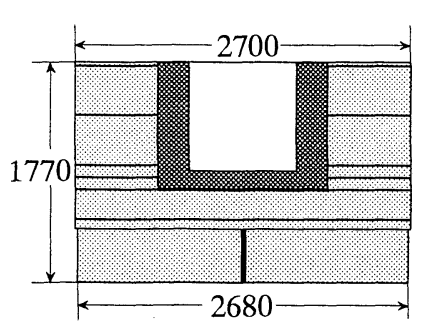

a front view

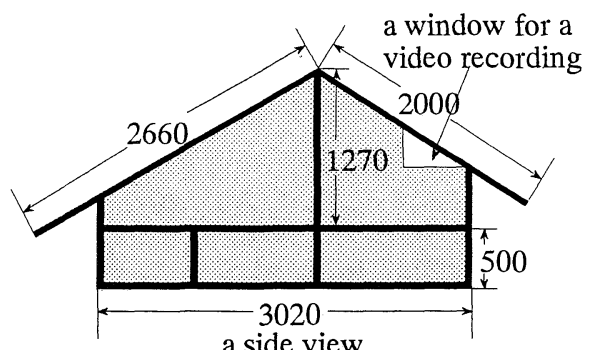

a side view

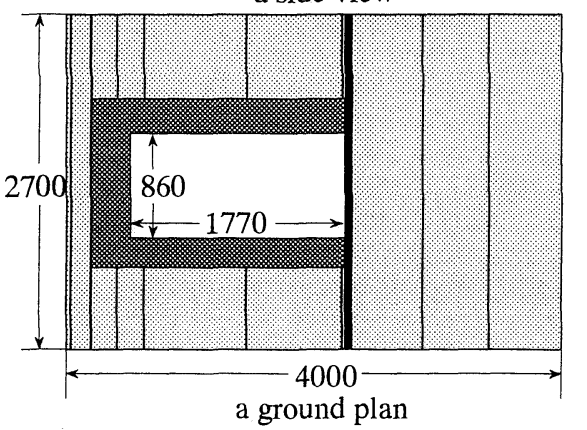

FIGURE 1 Schematic of roof model (unit : $\mathrm{mm}$ ) 
Japanese cypress bark roof is composed of bark pieces of Japanese cypress. Each piece is about $50 \mathrm{~cm}$ in length, $20 \mathrm{~cm}$ in width, and approximately $2 \mathrm{~mm}$ in thickness. The pieces are piled up from the eaves of the roof with approximately $4 \mathrm{~cm}$ of shifting. The thickness of the roof ranges for 10 to $15 \mathrm{~cm}$.

\section{SHINGLE-ROOFED}

Shingle-roofed is composed of shingle pieces. Each piece is about $40 \mathrm{~cm}$ in length, 10 to $20 \mathrm{~cm}$ in width, and approximately $3 \mathrm{~mm}$ in thickness. The pieces are piled up from the eaves of the roof with approximately $3 \mathrm{~cm}$ of shifting. The thickness of the roof ranges for 5 to $10 \mathrm{~cm}$.

\section{DESCRIPTIONS OF THE EXPERIMENTS}

FIGURE 1 shows a schematic diagram of the structure model used for the experiments. The specifications of sensors are shown in TABLE 1. The sensors were placed as illustrated in FIGURE 2 and FIGURE 3. We tested a variety of detectors in the experiments such as the infrared detector, the ultraviolet detector and photoelectric smoke detector are prepared based on the fire service law of Japan. Photoelectric smoke detector was analog type. Flame sensor was the UVtron-R2868 made by Hamamatsu photonics Co.Ltd., and was sensitive to faint ultraviolet rays from a flame. Thermocouples of type C-A were used for the measurement of temperature. The infrared detector, the ultraviolet detector and the flame sensor are known generically as flame detectors. The experimental conditions and measured items are listed in TABLE 1. The roof

TABLE 1 Experimental conditions and measured items

\begin{tabular}{|l|c|c|c|c|c|c|}
\hline test No. & 1 & 2 & 3 & 4 & 5 & 6 \\
\hline roof material & $\begin{array}{c}\text { cogon- } \\
\text { grasses }\end{array}$ & $\begin{array}{c}\text { cogon- } \\
\text { grasses }\end{array}$ & $\begin{array}{c}\text { japanese } \\
\text { cypress }\end{array}$ & $\begin{array}{c}\text { japanese } \\
\text { cypress }\end{array}$ & shingle & shingle \\
\hline wind velocity & $0 \mathrm{~m} / \mathrm{s}$ & $2 \mathrm{~m} / \mathrm{s}$ & $0 \mathrm{~m} / \mathrm{s}$ & $3 \mathrm{~m} / \mathrm{s}$ & $0 \mathrm{~m} / \mathrm{s}$ & $3 \mathrm{~m} / \mathrm{s}$ \\
\hline $\begin{array}{l}\text { atmospheric } \\
\text { temperature }\end{array}$ & $12.5^{\circ} \mathrm{C}$ & $10.0^{\circ} \mathrm{C}$ & $18.5^{\circ} \mathrm{C}$ & $8.0^{\circ} \mathrm{C}$ & $21.5^{\circ} \mathrm{C}$ & $3.5^{\circ} \mathrm{C}$ \\
\hline humidity & $45 \%$ & $22 \%$ & $52 \%$ & - & $49 \%$ & - \\
\hline ignition & fireworks & $\begin{array}{c}\text { charcoal } \\
\text { fire }\end{array}$ & $\begin{array}{c}\text { charcoal } \\
\text { fire }\end{array}$ & $\begin{array}{c}\text { charcoal } \\
\text { fire }\end{array}$ & $\begin{array}{c}\text { charcoal } \\
\text { fire }\end{array}$ & $\begin{array}{c}\text { charcoal } \\
\text { fire }\end{array}$ \\
\hline video & $\mathrm{O}$ & $\mathrm{O}$ & $\mathrm{O}$ & $\mathrm{O}$ & $\mathrm{O}$ & $\mathrm{O}$ \\
\hline thermocouple & - & 10 points & - & 10 points & - & 10 points \\
\hline flame sensor & 1 point & 1 point & 1 point & 1 point & 1 point & 1 point \\
\hline UV detector & 1 point & 1 point & 1 point & 1 point & 1 point & 1 point \\
\hline IR detector & 1 point & 1 point & 1 point & 1 point & 1 point & 1 point \\
\hline $\begin{array}{l}\text { photoelectric smoke } \\
\text { detector }\end{array}$ & 4 points & 4 points & 2 points & 2 points & 2 points & 1 point \\
\hline
\end{tabular}




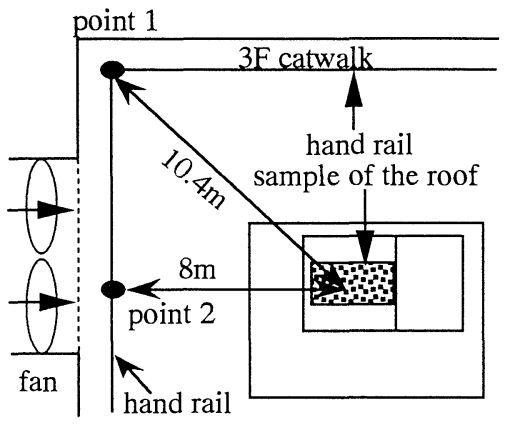

a ground plan

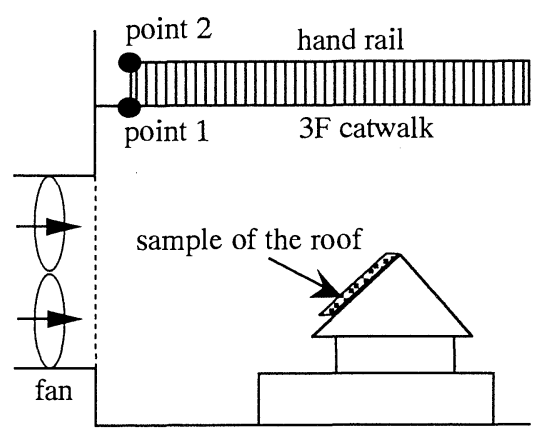

a side view

FIG URE 2 Experimental set up

( Flame sensor was installed at point 1 , the ultraviolet and the infrared detectors were installed at point 2.)

for the experiment was mounted on the thick and black frame illustrated in a ground plan of FIGURE 1. The thatched roof with dimensions of $90 \mathrm{~cm}$ wide, $200 \mathrm{~cm}$ long, $40 \mathrm{~cm}$ thick was made by thatched roof artisan. Japanese cypress bark roof and Shingle-roofed, whose dimensions were $90 \mathrm{~cm}$ wide, $180 \mathrm{~cm}$ long. Those roofs were obtained by cutting down from the real cultural assets buildings. To ignite the surface of the roof, charcoal fire was placed at the Point 6 shown in FIGURE 3. The selection of the ignition source was made based on the fact that flying sparks from a bonfire and fireworks are responsible for real roof-surface fires.

The thatched roof could not be ignited by the charcoal fire without wind. Therefore fireworks were used in dead calm. The wind was created in front of the structure model using the air blower. The temperature in the attic was monitored by thermocouples. The smoke inflow into the attic was observed by a video camera and smoke detectors. The surface of the roof was observed by the flame detectors and the optical fiber thermometer. The experimental room was spacious and was not air-conditioned.

\section{EXPERIMENTAL RESULTS AND DISCUSSION}

\section{DIFFERENCE IN COMBUSTION CHARACTERISTICS OF EACH ROOF MATERIALS}

\section{Thatched roof}

The thatched roof is less ignitable than the other two types of roof. Under the wind, the thatched roof was ignited by $1.5 \mathrm{~cm}$ cubic charcoal fire. Without wind, thatched roof could not be ignited by charcoal fire. After the flaming, combustion spread rapidly. In the experiment without wind, the combustion area grown to $0.25 \mathrm{~m}^{2}$ within 2 minutes, after flaming. Under the wind, it took several tens of seconds for combustion are a to grow to $0.25 \mathrm{~m}^{2}$. The fla ming area of $0.25 \mathrm{~m}^{2}$ is approximate minimum size at which the infrared detector can 


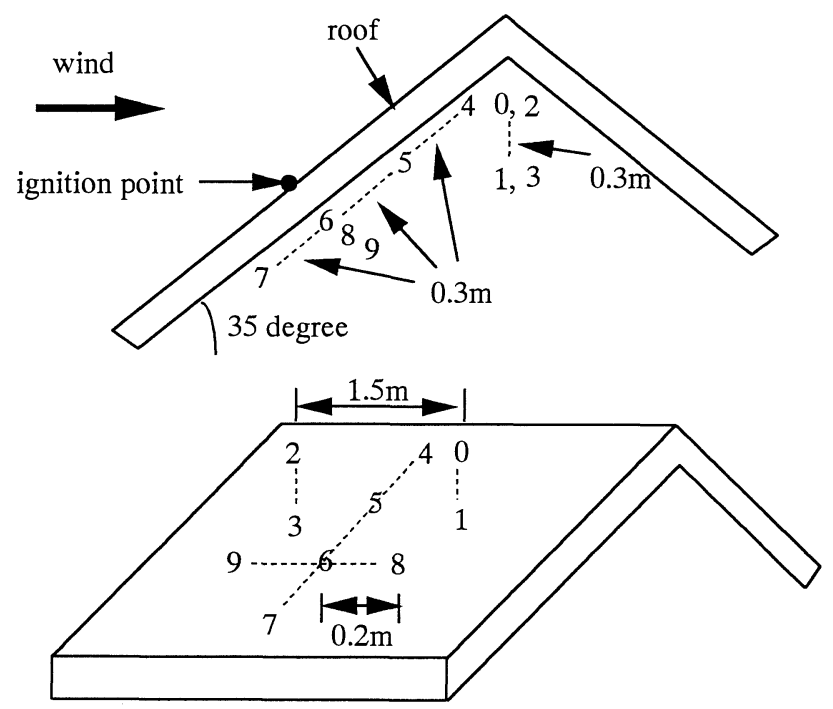

FIGURE 3 Schematic diagram of thermocouples and photoelectric smoke detectors (Thermocouples were installed at point 0 to 9, smoke detectors were installed at point 0 to 3 .)

detect the flame at $8 \mathrm{~m}$ away from the model roof. The combustion tend to spread upward with flaming. The rate of upward fire spread was more than 5 times as rapid as downward spread. And the rate of sideward fire spread was approximately 1 to 1.5 times as rapid as downward speed. Compared with the other kinds of botanical roofs, thatched roof had much more significant flames which caused faster flame spread.

\section{Japanese cypress bark roof}

Japanese cypress bark is easy to smolder because the surface of the bark is fluffy. Japanese cypress bark roof was ignited by $1 \mathrm{~cm}$ cubic charcoal fire. Under the wind, a flaming on the roof-surface started 3 minutes after the ignition. After the ignition, smoldering area spread with sudden flaming. Smoldering spread was slow. It took 15 to 60 minutes for smoldering area to grow to $0.35 \mathrm{~m}^{2}$ after flaming under the wind. Without wind, it took more than 60 minutes for smoldering area to grow to $0.35 \mathrm{~m}^{2}$. The combustion area of $0.35 \mathrm{~m}^{2}$ is approximate minimum size at which the infrared detector can detect the combustion at $8 \mathrm{~m}$ away from the roof. The smoldering tend to spread downward. The rate of upward fire spread was 0.1 to 0.5 times as rapid as downward spread and the rate of sideward fire spread was approximately 0.2 to 0.5 times as rapid as downward spread. Because the smoldering tends to spread toward the direction of larger amount of oxygen supply, the combustion spreads downward where the pieces of the bark are less overlapped.

Shingle-roofed

Shingle was easiest to be ignited between three kinds of the roof materials 
tested. Flaming on the shingle-roofed surface started within 3 minutes under the wind of $3 \mathrm{~m} / \mathrm{s}$. To ignite the shingle without the wind, three pieces of $1.5 \mathrm{~cm}$ cubic charcoal fire were placed continuously. It took 15 to 40 minutes for flaming area to grow to $0.25 \mathrm{~m}^{2}$ after flaming under the wind. The flaming area of $0.25 \mathrm{~m}^{2}$ is approximate minimum size at which the infrared detector can detect the flame at $8 \mathrm{~m}$ away from the roof. Without wind, the combustion spread was slow. Because of the slow combustion spread, the infrared detector did not respond during the experiment. The smoldering tend to spread inward. Once a hole was made, the flaming was observed around the hole. Then the combustion spread upward at the both faces of shingle with the flaming. The combustion speeds of every direction were much the same before a hole had be en made. After a hole had been made, the rate of upward fire spread was approximately 2 to 3 times as rapid as downward spread. And the rate of sideward fire spread was about 0.7 to 1.5 times as rapid as downward spread.

\section{TEMPERATURE AND SMOKE DENSITY PROFILES IN THE ATTIC}

\section{Thatched roof}

FIGURE 4 shows the temperature profile at the attic during the fire test with wind. At the place just below the igniting point, the temperature began to rise 2 minutes after the flaming on the roof-surface. Hot air intruded into the attic vertically, and the flow did not follow the direction of the cogongrasses stalk. It was not affected by the direction of the cogongrasses stalk, as if the flow was forced by the wind outside the roof. Within 2 minutes, te mperatures at all observed points exceeded $100^{\circ} \mathrm{C}$. The burnt roof area was $0.1 \mathrm{~m}^{2}$ and it was flaming when temperature rise of $10^{\circ} \mathrm{C}$ was observed at just below the

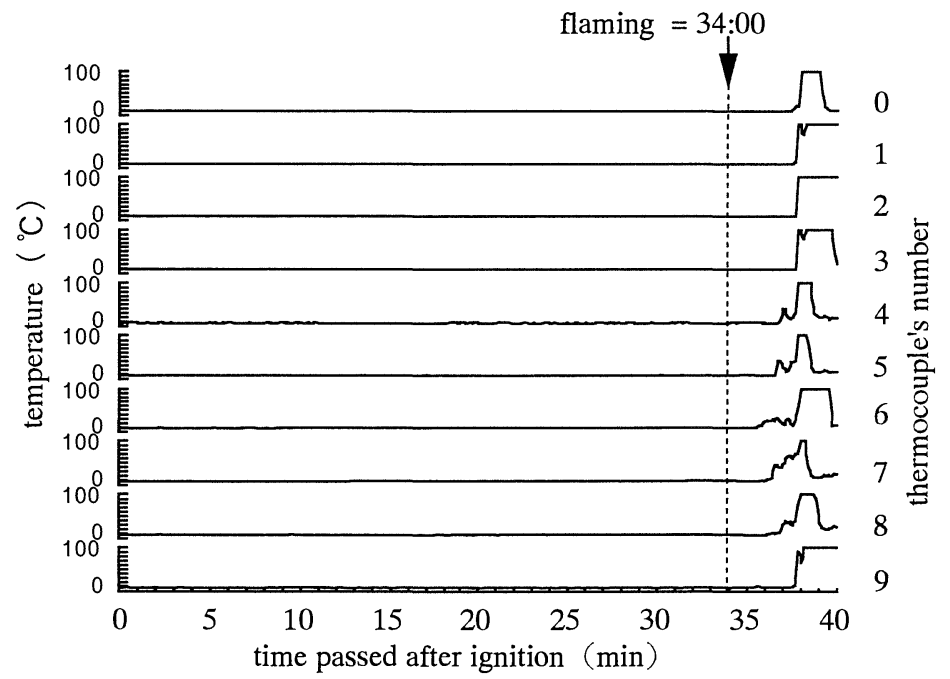

FIGURE 4 Output signals of thermocouples (test 2: thatched roof) 
igniting point. Because of the rapid flame spread on the roof-surface, the area through which the smoke intrude into the attic was broad and the rate of temperature rise was high.

FIGURE 5 shows the change in smoke density in the attic with time. At the experiment with wind, it was revealed that the rise in smoke density was observed about 2 minutes prior to the flaming, during the smoldering stage of combustion. The smoke density exceeded the alarm level of smoke detector $(5 \% / \mathrm{m})$ about 1 minute prior to the flaming. When the smoke detector gave smoke density of $5 \% / \mathrm{m}$, the combustion on the roof-surface was in the smoldering stage. These mean that the smoke intrude into the attic. At the experiment without wind, even if there was no smoldering, the smoke detector gave smoke density of $5 \% / \mathrm{m}$ when the combustion area grew up to be $0.6 \mathrm{~m}^{2}$. The time when smoke detector gave smoke density of $5 \% / \mathrm{m}$ was 6 minutes after the flaming on the surface of the roof. This response time was half of the response time of the other roof type.

(owing to ignition with fireworks, the fire blazed up with ignition and spread rapidly.)

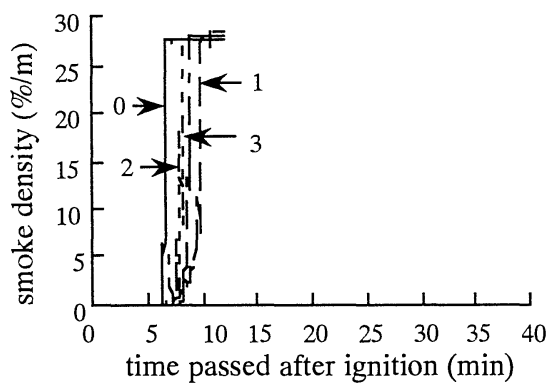

(a) test 1

wind velocity $=0 \mathrm{~m} / \mathrm{s}$

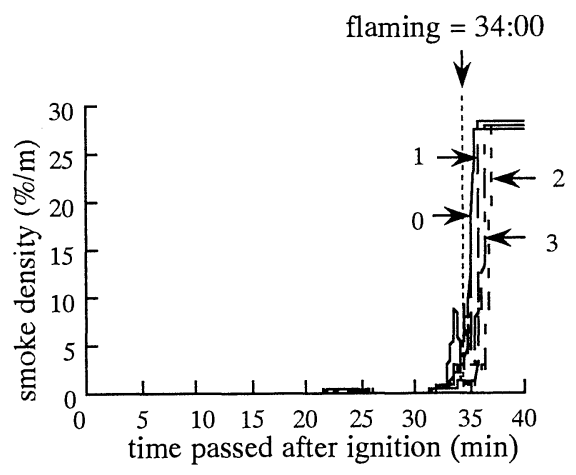

(b) test 2

wind velocity $=2 \mathrm{~m} / \mathrm{s}$

FIG URE 5 Output of photoel ectric smoke detectors

( thatched roof)

Japanese cypress bark roof

FIGURE 6 shows the change in temperature at the attic during the fire test. At a point $30 \mathrm{~cm}$ above of the point just opposite to the fire point (the backside point), the temperature rose about $5^{\circ} \mathrm{C}$ before the flaming on the surface of the roof. The burnt roof area was less than $0.01 \mathrm{~m}^{2}$ and it was flaming when temperature rise of $10^{\circ} \mathrm{C}$ was observed at the $30 \mathrm{~cm}$ above the backside point. After the temperature rose at the $60 \mathrm{~cm}$ above the backside point, the temperature started to rise at the top in the attic. At the both side and below the backside point, there were no striking changes during 7 minutes after the flaming on the roof-surface. These mean that the area where hot air intruded into the attic was narrow. This area was about $60 \mathrm{~cm}$ long and $40 \mathrm{~cm}$ wide.

FIGURE 7 shows the change in smoke density with time within the attic. At the experiment with wind, it was revealed that the rise in smoke density was 


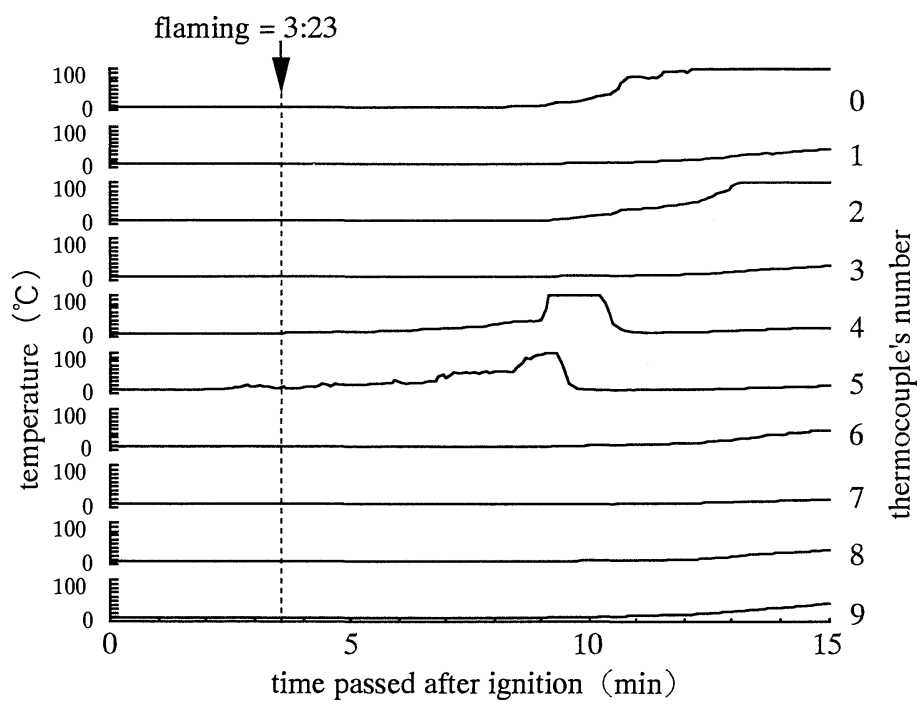

FIGURE 6 Output signals of the rmocouples

( test 4 : Japanese cypress roof)

observed about 1 minute prior to the flaming. The smoke density exceed the alarm level of smoke detector $(5 \% / \mathrm{m})$ about 3 minutes prior to the flaming. When the smoke detector gave a smoke density of $5 \% / \mathrm{m}$, the combustion on the surface of the roof was in the flaming stage and the combustion area was less than $0.01 \mathrm{~m}^{2}$. At that time, the thermocouple 4 located at $60 \mathrm{~cm}$ above the

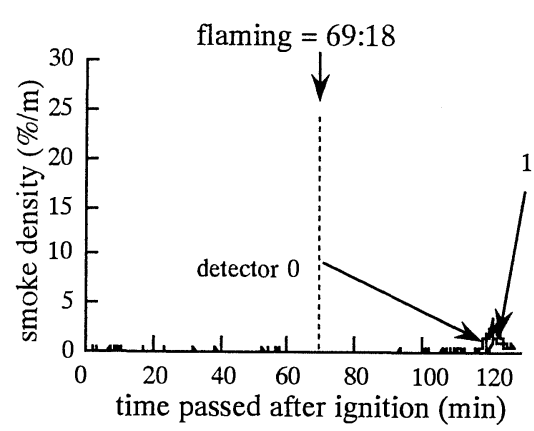

(a) test 3

wind velocity $=0 \mathrm{~m} / \mathrm{s}$

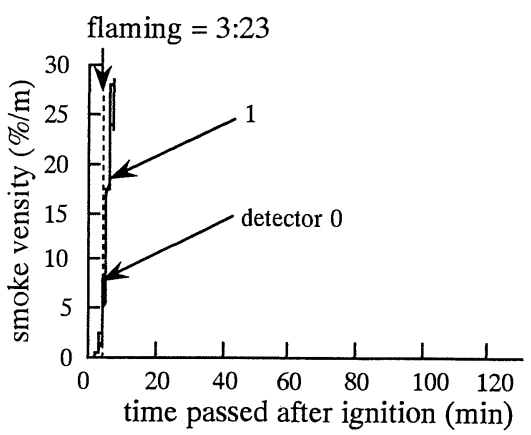

(b) test 4 wind velocity $=3 \mathrm{~m} / \mathrm{s}$

FIG URE 7 Output of photoel ectric smoke detectors

( Japanese cypress roof) 
backside point gave $10^{\circ} \mathrm{C}$ rise in temperature. At the experiment without wind, the smoke density in the attic did not reach an alarm level of the smoke detector even 1 hour after the flaming.

\section{Shingle-roofed}

Temperature profiles measured with thermocouples in the windy case are illustrated in FIGURE 8. The thermocouple at the point 5 gives $10^{\circ} \mathrm{C}$ rise in temperature. At the time, the burning area on the surface of the roof was less than $0.01 \mathrm{~m}^{2}$. The condition of fire was flaming. The thermocouples at point 4 and 6 gave rise of temperature. Then, temperature at point 8,9 and 0 begun to rise slowly. Owing to this tendency continued till the fire penetrated through the roof, this showed that the burning area spread long elliptically lengthways. The area where heat flow entered was about $60 \mathrm{~cm}$ long and $40 \mathrm{~cm}$ wide till the fire penetrated through the roof. Because of the fresh air blown into the attic after the fire penetrated through the roof, temperatures of some points went down. But temperature at top point of the attic (point 0) didn't drop.

Change in smoke density in the att ic is shown in FIGURE 9. In the windy case, smoke detector caught $5 \% / \mathrm{m}$ rise of smoke density in 2 minutes after flaming. And more than 1 minute later, the smoke density exceeded the upper measurement $\lim$ it $(25 \% / \mathrm{m})$. Then the state of combustion was a flaming fire and burning area was less than $0.01 \mathrm{~m}^{2}$. Before the fire penetrate through the roof, a smoke detector can give an alarm. In the windless case, in over 10 minutes after flaming smoke detector caught a rise of $5 \% / \mathrm{m}$ smoke density and smoke density soon exceeded the upper measurement limit $(25 \% / \mathrm{m})$.

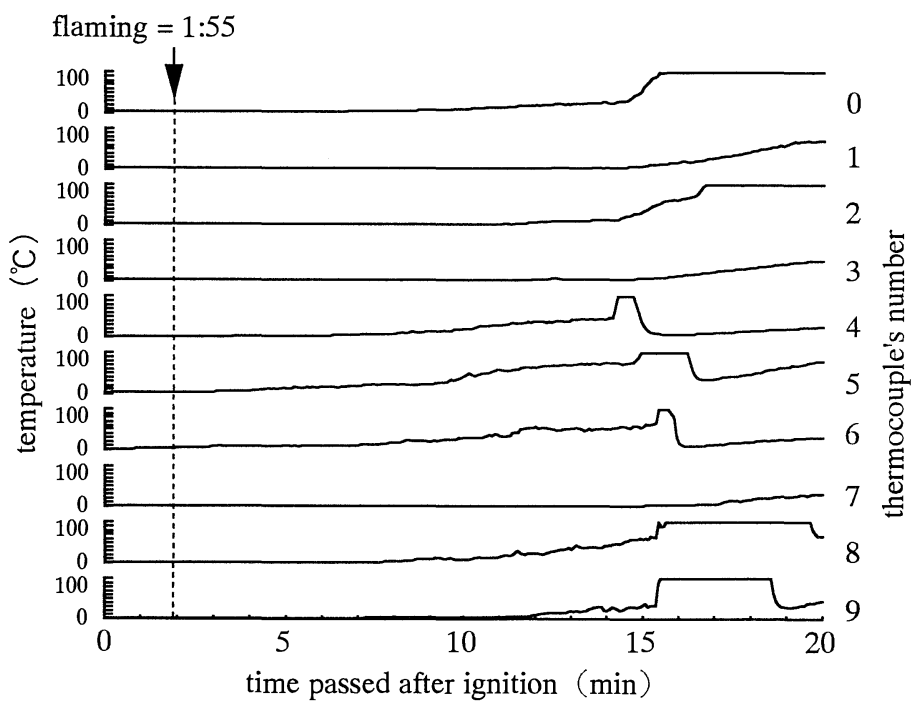

FIGURE 8 Output signals of the rmocouples

(test 6 : shingle-roofed) 


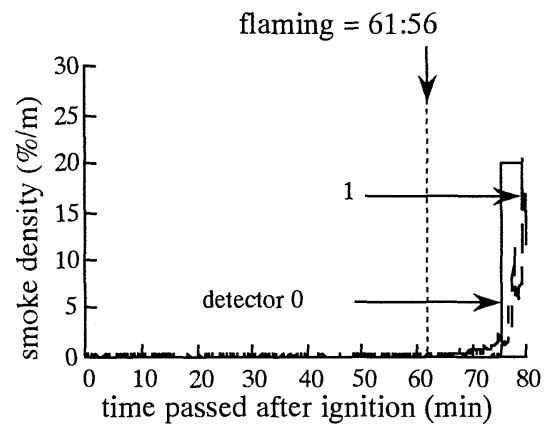

(a) test 5

wind velocity $=0 \mathrm{~m} / \mathrm{s}$

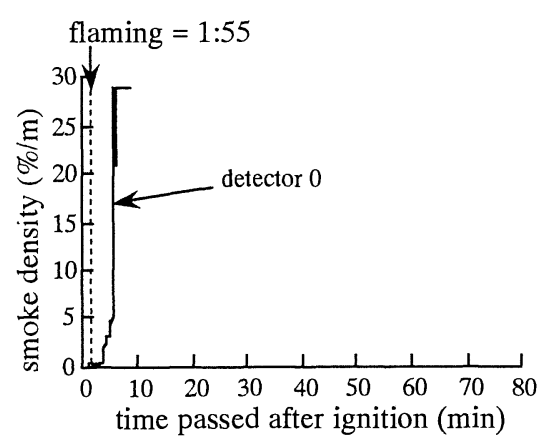

(b) test 6

wind velocity $=3 \mathrm{~m} / \mathrm{s}$

FIGURE 9 Output of photoelectric smoke detectors ( shingle-roofed)

\section{RESPONSE OF FLAME DETECTORS}

We are investigating effective methods to extinguish roof-surface fires now, therefore we evaluate the detectors based on the performance of an early detection. Response times of the infrared detector, the ultraviolet detector and flame sensor set up in the outside is listed in TABLE 2. The infrared and the ultraviolet detector are adjusted not to run by detecting lower intensity of light than the threshold level, to prevent false alarms. The flame sensor caught sudden flaming and ran. As a result, the flame sensor ran faster several minutes to several tens of minutes than the infrared detector and the ultraviolet detector (TABLE 2). And the ultraviolet detector runs faster than the infrared detector.

The flame sensor can detect roof surface fire early, but this sensor has a disadvantage that it responds to a noise including ultraviolet rays. This sensor can be used in limited cases. For example, the flame sensor is expected to pre-alarm fires in the system of a building's supervision that is possible to check the spot from pre-alarm.

TABLE 2 Response time of flame detectors

(minute : second)

\begin{tabular}{|l|c|c|c|c|c|c|}
\hline \multicolumn{1}{|c|}{ test No. } & 1 & 2 & 3 & 4 & 5 & 6 \\
\hline flame sensor & $0: 05$ & $34: 1$ & $69: 18$ & $3: 23$ & $61: 56$ & $1: 56$ \\
\hline UV detector & $0: 45$ & $34: 1$ & $116: 7$ & $13: 26$ & NR & $8: 43$ \\
\hline IR detector & $1: 49$ & $34: 13$ & $116: 33$ & $16: 07$ & NR & $17: 48$ \\
\hline
\end{tabular}

NR : not response 


\section{CHARACTERISTICS OF COMBUSTION}

It is difficult to fire the dry cogongrasses. But once flames occurred and blazed up, a fire spreads quickly.

Japanese cypress roof keeps on smoldering. While brazing small flames, fire spreads downward the roof-surface.

Shingle-roofed's fire keeps on smoldering toward a reverse side of the roof and a smoldering penetrates through the roof. After that fire spreads toward the top of the roof.

\section{FIRE DETECTION IN THE ATTIC}

Fire Detection with smoke detector

If there is a head wind, it is possible to detect $5 \% / \mathrm{m}$ smoke density for fires of all type of the roof materials with smoke detectors in an attic. When a smoke density reaches $5 \% / \mathrm{m}$, burning are still smoldering fire in the thatched roof and flaming fire in the others. At the detection time the burning area in all types roofs are under $0.01 \mathrm{~m}^{2}$.

If there is no wind, it is possible to detect $5 \% / \mathrm{m}$ smoke density for the thatched roof. At this stage, burning are a is $0.6 \mathrm{~m}^{2}$. In the shingle-roofed, till fire penetrated through the roof, the detector does not run. In the Japanese cypress, it is difficult for the smoke detectors to detect a fire.

Fire Detection with temperature in the windy case

The thermocouples pick up heat air current from a point just opposite to the fire point to the $40 \mathrm{~cm}$ upper point. After that, temperature at the top of the attic rise. When some one of the thermocouples in the attic caught $10^{\circ} \mathrm{C}$ rise in temperature, burning are a of the roof-surface is $0.1 \mathrm{~m}^{2}$ in thatched roof and $0.01 \mathrm{~m}^{2}$ in the other roofs respectively. Because the temperature rose after fire turned from smoldering to flaming in all cases, it is difficult for thermal sensors to detect a smoldering fire.

\section{DETECTION FROM THE OUTSIDE OF THE BUILDING}

Flame sensor activated by the ultraviolet ray from a flame can detect small fires. However, due to lacking of the steps taken for a false alarm, this sensor can be used in limited case. It is that the flame sensor is expected to be used for pre-alarm sensor under the system of building's supervision which is possible to check the spot from pre-alarm.

\section{REFERENCES}

1. Tamura, H., Takahashi, S., Yamashita, K., Aizawa, M.,"Study on the Fire Protection Method of Cultural Properties Buildings which are thatched with the Cogongrasses and others (part-2 Fire Detection)", Proceeding of Annual Meeting of the Japan Association for Fire Science and Engineering, pp.8-11, 
1995

2. Takahashi, S., Tamura, H., Yamashita, K., "Study on the Fire Protection Method of Cultural Properties Buildings which are thatched with the Cogongrasses and others (part-1 Fire Characteristic and Suppression)", Proceeding of Annual Meeting of the Japan Association for Fire Science and Engineering, pp.70-73, 1995

3. Tamura, H., Aizawa, M., Yamashita, K., "Study on Fire Detection of Cultural Properties Building with Vegetable-thatched roof (Temperature and Smoke Density in an Attic)", Proceeding of Annual Meeting of the Japan Association for Fire Science and Engineering, pp.48-51, 1996

4. Aizawa, M., Tamura, H., Yamashita, K.,"Study of the Fire Detection in Building filled with a thatched Roof (Optical Fiber Thermometer)", Proceeding of Annual Meeting of the Japan Association for Fire Science and Engineering, pp.44-47, 1996

5. Fire brigade city of Kyoto, "Study on the Combustion of Japanese cypress", 1977 